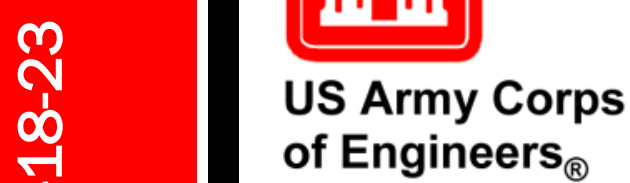

\title{
WERDC
}

Engineer Research and

Development Center

\section{Analysis of Steam and Hot Water Heat Systems at Fort Polk, LA}

\section{Retrofit Options}

Alexander M. Zhivov, John L. Vavrin, Alfred Woody,

August 2018

Stephen Richter, and Norbert Paetz

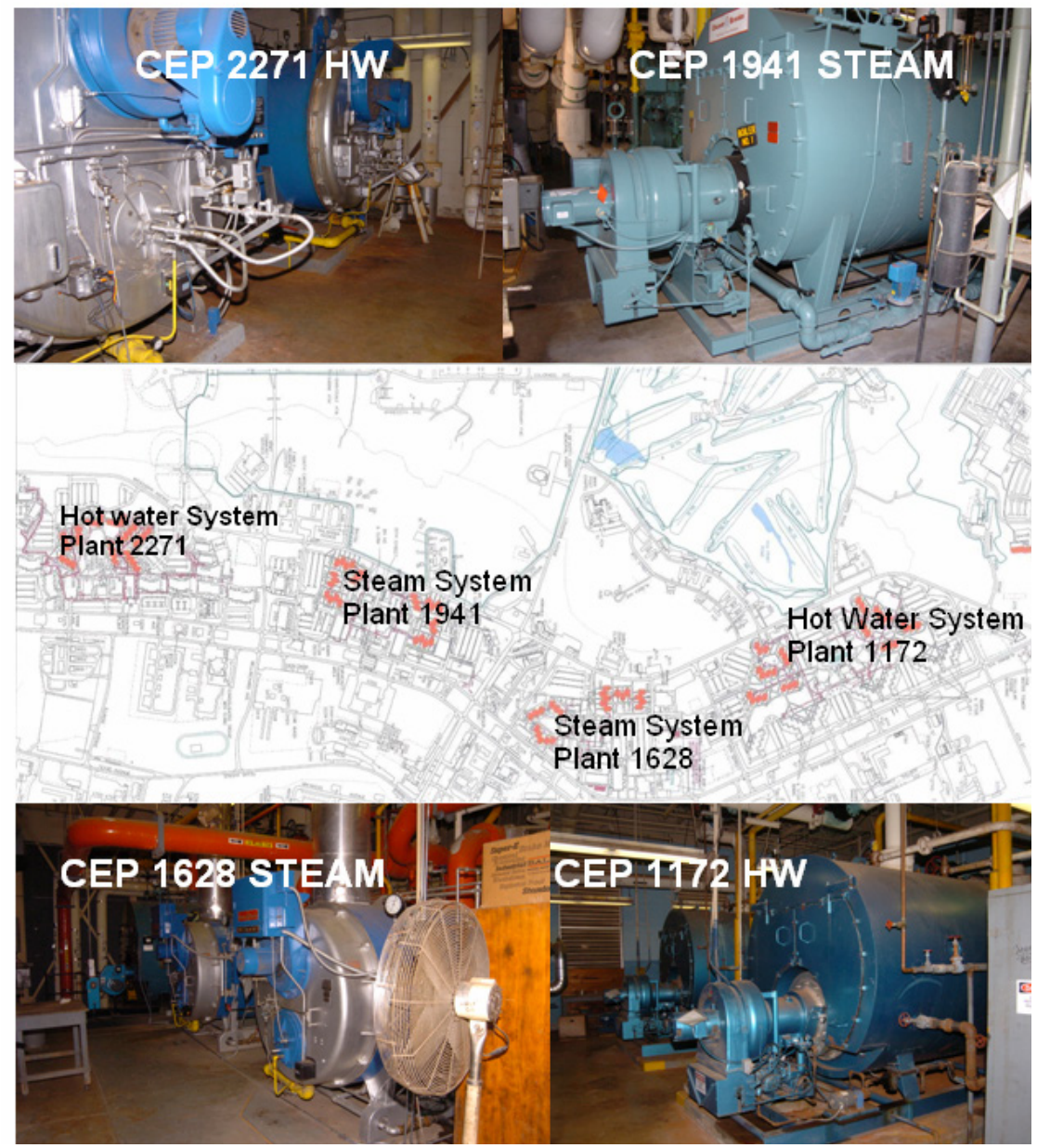


The U.S. Army Engineer Research and Development Center (ERDC) solves the nation's toughest engineering and environmental challenges. ERDC develops innovative solutions in civil and military engineering, geospatial sciences, water resources, and environmental sciences for the Army, the Department of Defense, civilian agencies, and our nation's public good. Find out more at www.erdc.usace.army.mil.

To search for other technical reports published by ERDC, visit the ERDC online library at http://acwc.sdp.sirsi.net/client/default. 


\section{Analysis of Steam and Hot Water Heat Systems at Fort Polk, LA}

\section{Retrofit Options}

Alexander M. Zhivov and John L. Vavrin

Construction Engineering Research Laboratory (CERL)

U.S. Army Engineer Research and Development Center

2902 Newmark Dr.

Champaign, IL 61824

Alfred Woody

Ventilation/Energy Applications PLLC

3087 Glengrove Drive

Rochester Hills, MI 48309

Stephen Richter

GEF Ingenieur AG

Norbert Paetz

MVV Energie

Final Report

Approved for public release; distribution is unlimited.

Prepared for U.S. Army Corps of Engineers

Washington, DC 20314-1000

Under Project Requisition No. 127396, Activity A1020, "Annex 46 Holistic Assessment Toolkit on Energy Efficient Retrofit Measures for Government Buildings (EnERGo)" via Military Interdepartmental Purchase Request (MIPR) 6CCERB1011 


\section{Abstract}

Fort Polk is an active Army installation, with about 70 barracks, operations, and administrative facilities, all of which are heated and cooled via central heating and cooling plants. Two of the building groups are heated by distributing hot water and the other two by steam. Although the existing equipment in the heating plants appears to be in good condition, the system's underground heating piping has significant maintenance problems. Also, while the isolated chiller plants perform well, they are not optimized for the chiller demand. This work assessed the heating system at Fort Polk, LA and evaluated heating improvement measures for application at that installation, and concluded that (1) potential savings were not significant enough to warrant the high investments required for retrofit, and (2) available energy flow data were insufficient to perform a complete performance analysis. It was recommended that the installation implement and enforce a metering campaign to improve its energy use database and to better enable informed decisions about heating system improvements.

DISCLAIMER: The contents of this report are not to be used for advertising, publication, or promotional purposes. Citation of trade names does not constitute an official endorsement or approval of the use of such commercial products. All product names and trademarks cited are the property of their respective owners. The findings of this report are not to be construed as an official Department of the Army position unless so designated by other authorized documents. 


\section{Executive Summary}

Fort Polk is an active Army installation, the home of the Joint Readiness Training Center, which provides contingency training for the Army's light infantry and special operation forces. Fort Polk is home to the Warrior Brigade, which contains several combat support units, the responsibilities of which include supporting the installation. Additionally, Fort Polk is the home for the newly activated 4th Brigade, 10th Mountain Division.

The installation has about 70 barracks, operations, and administrative facilities located in a corridor between two major roads. These buildings are divided into four groups, all of which are heated and cooled via central heating and cooling plants. The heating energy is provided by distributing hot water to two building groups and steam to the other two groups. The two hot water heating plants are located in Bldgs, 1172 and 2271, which service the building groups at either end of the complex. The two steam plants are located in Bldgs 1628 and 1941, which service the groups in the middle of the complex.

The existing equipment in the heating plants appears to be in good condition. However, maintenance problems in the underground heating piping system cause leaks that waste energy and treated water. The isolated chiller plants perform well, but the chiller sizes are not optimized for the chiller demand. Most of the buildings consist of a two-pipe distribution system, which means that the installation must choose to use either the heating or cooling medium exclusively. Thus, chilled water is supplied on a seasonal basis even though there is an occasional chilled water demand in the winter. Some buildings are being renovated to have a four-pipe system to accommodate both heating and cooling. Still, the energy use records available for these plants are incomplete and lack sufficient accuracy to determine the energy costs of these wastes and inefficiencies.

This work was undertaken to identify and recommend cost effective improvements to the heating system. Beyond improving cost effectiveness, the recommended improvements must also provide comfort to building occupants, ease of operation, a minimum of required maintenance, and a minimum of energy waste-at a reasonable installation cost. 
Six heating improvement measures were evaluated for application to Fort Polk:

1. Switch heating systems in Boiler Plants 1628 and 1941 from steam to hot water heating

2. Reduce the hot water temperature supplied in the summer by all four plants

3. Use variable hot water flow where applicable

4. Connect Boiler Plants 1628 and 1941 with underground hot water pipe

5. After connecting the piping systems in Boiler Plants 1628 and 1941, configure Boiler Plant 1941 to make hot water only

6. Make hot water using jacket water from the engine driven chiller in Boiler Plant 1941.

Fort Polk is located in west central Louisiana in an area with high humidity and cooling demand, but a low heating demand. Consequently, heating plays a minor role in the overall building comfort and energy costs. The warm climate contributes to a low heating energy use so that savings realized from making heating system improvements seldom economically justify the required investments. The annual natural gas use in the southern part of Fort Polk where these plants are located is 210,000 million Btu/yr, which translates to a value of $\sim \$ 2.5$ million.

The estimated cost to implement the first five heating improvement is almost \$3.5 million dollars. The estimated annual heating energy savings using a cost of $\$ 10 /$ million Btu is a maximum of $\$ 300,000 / y r$ (more likely to be less than $\$ 200,000 / y r)$. Additional maintenance and operating savings would amount to $\sim \$ 100,000 / y r$. The resulting simple payback for measures 1-5 range from 10 to 12 years, and the simple payback for measures $1-3$ is more than 9 years.

The cost-effectiveness of the sixth measure is not immediately apparent since the cost to operate the engine-driven chiller is higher than that of the electric-powered chillers; thus it is seldom run. However, the enginedriven chiller has greater operational efficiency than electric chillers during part load operations. It is recommended that the loading of the chillers be monitored over several months to determine when the engine-driven chiller can be best used. If the engine-driven chiller can operate at a lower cost than one of the electric chillers, then it may be appropriate to install a heat exchanger to the radiator cooling water circuit and pass boiler makeup water through the engine-driven exchanger.

There is a project at Fort Polk to improve the performance of the chilled water plants. This will provide improved comfort in the barracks and unit 
operations facilities, improve energy efficiency, reduce water losses, and reduce humidity (which can cause mold). This project will enable the chilled water systems to operate year round, will convert the continuous chilled/hot water flow system to variable flow, will improve the efficiency of operation, will switch two steam heating systems to a hot water system, and will replace sections of the underground distribution systems that require significant repairs.

A project delivery team from the Engineer Research and Development Center, Construction Engineering Research Laboratory (ERDC-CERL), composed of subject matter experts from the Corps and private consultants, reviewed the Department of Defense (DD) Form 1391* for this project and concluded that the approach and concept were correct for this application. The team reached the following conclusions

1. This project would enable the cooling systems to operate in the winter time. On the occasional warm day, the system could cool the building spaces and keep the occupants kept comfortable. Currently, facilities receive only heating in the winter and on warm winter days, the space temperatures become uncomfortably warm. Some occupants turn off their ventilation systems to keep building temperatures comfortable.

2. In the winter, the inability to cool the ventilation air in the barracks leads to mold problems. Currently, the humidity created by showers remains in the living quarters, and the building's exhaust system draws more humid air from outside into the barracks. With no chilled water, the heating, ventilating, and air-conditioning (HVAC) cooling coil cannot reduce the rooms' humidity level.

3. The chiller plants will be interconnected to provide better chiller operations at low winter time loads, when one or two chillers can provide chilled water for the entire site. Also, this will increase the security of supply; when one chiller's operation is interrupted, another chiller can carry the load.

4. In the winter time, a water-side economizer can provide the cooling water. This system uses cooling tower water as the cooling source. A heat exchanger keeps the cooling tower water separate from the chilled water. When the outdoor temperature drops below $50^{\circ} \mathrm{F}$ a cooling tower can generate $55^{\circ} \mathrm{F}$ chilled water, which is then sent to the buildings.

\footnotetext{
* The DD Form 1391 Processor System is the web-accessible system that assists users in preparing, submitting, reviewing, correcting, printing and archiving DD Forms 1391 and their related data, in accordance with Army Regulation (AR) 420-1, Army Facilities Management (2008, Washington, DC: Headquarters, Department of the Army [HQDA], https://armypubs.army.mil/epubs/DR_pubs/DR_a/pdf/web/r420_1.pdf).
} 
5. Variable flow water pumping systems should be installed to better use the chilled water. The current system sends chilled water to the buildings at a constant flow so, if not needed, the chilled water is bypassed and returned to the chiller plant, and a full $10^{\circ} \mathrm{F}$ drop is not achieved. If the building HVAC systems used two way valves, all the water would run through the cooling units, and none would be bypassed. The resulting reduction in water flow would yield pump energy savings and provide buildings that previously had difficulties getting adequate chilled water with more flow. 


\section{Contents}
Abstract
..iv

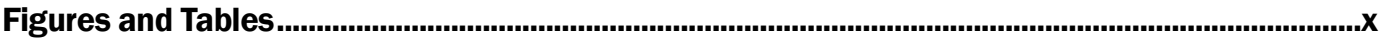

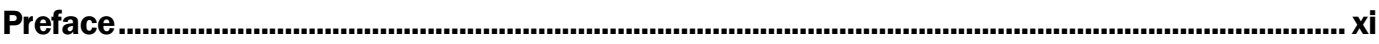
Unit Conversion Factors .................................................................................................................. xii
Acronyms and Abbreviations ..................................................................................................... xiii

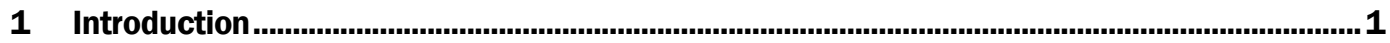

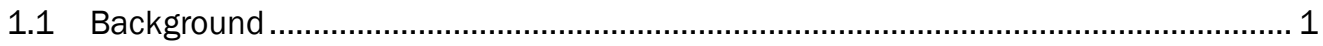

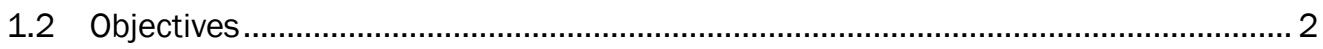

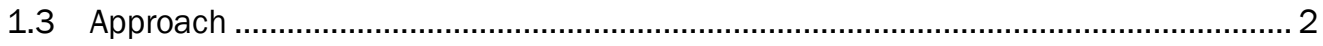

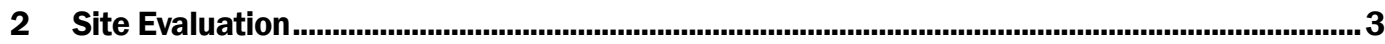

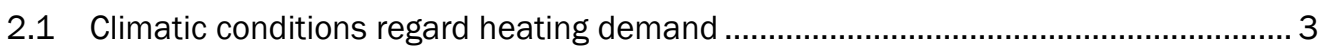

2.2 Estimation and evaluation of the current heating and hot water

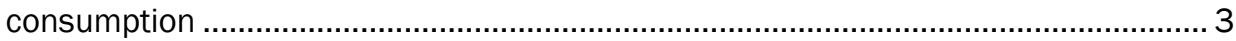

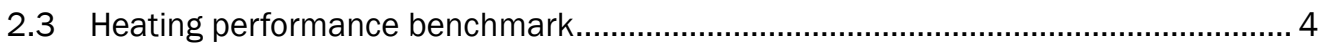

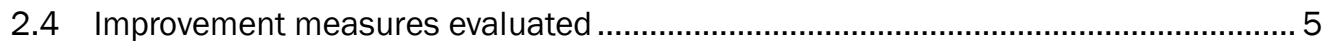

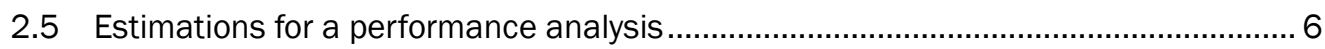

2.6 Steam heating conversion to variable temperature hot water heating ........................ 8

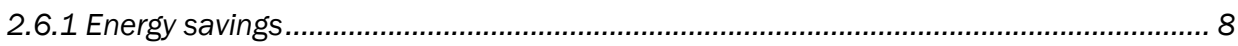

2.6.2 Savings from a steam to variable temp and flow hot water systems and required initial investments..................................................................................... 8

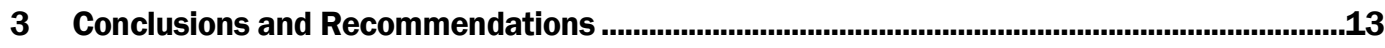

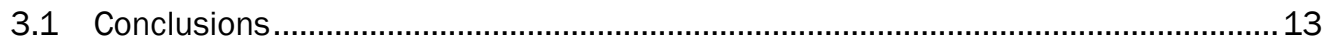

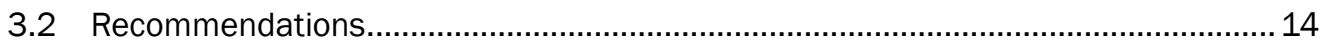

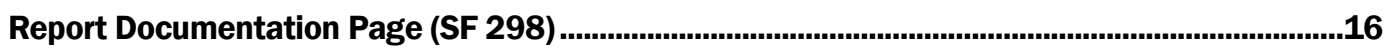




\section{Figures and Tables}

\section{Figures}

1-1 Fort Polk site map ..............................................................................................

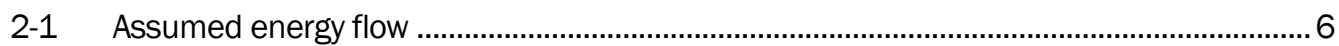

\section{Tables}

2-1 Heating degree days and design outdoor temperature for four district heating systems ..........................................................................................................

2-2 Important demand side parameters of four district heating systems ................................. 4

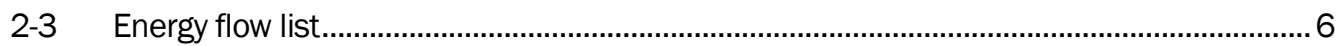

2-4 Overview on the four district heating systems at the southern part of Fort Polk and the installed boilers .............................................................................................. 6

2-5 List of assumed costs for a conversion of the two steam district heating systems to one hot water system with variable temperatures ............................................. 9

2-6 Overview on the sensitivities of the investments and potential savings and

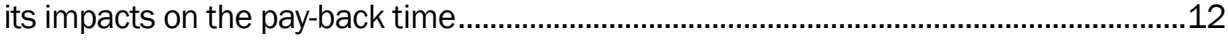




\section{Preface}

This work was done for Fort Polk, LA, under Project Requisition No. 127396, Activity A1020, "Annex 46 Holistic Assessment Toolkit on Energy Efficient Retrofit Measures for Government Buildings (EnERGo)," via Military Interdepartmental Purchase Request (MIPR) 6CCERB1011. The technical monitor was Paul Volkman, Headquarters, Installation Management Agency (HQIMA).

The work was managed and executed by the Energy Branch (CF-E) of the Facilities Division (CF), Construction Engineering Research Laboratory (CERL). The CERL principal investigator was Dr. Alexander Zhivov. Stephen Richter is associated with GEF Ingenieur AG, Germany; Norbert Paetz is associated with MVV Energie, Germany; and Alfred Woody is associated with Ventilation/Energy Applications PLLC, Rochester Hills, MI. At the time of publication, Giselle Rodriguez was Chief, CEERD-CFE, and Michelle Hanson was Chief, CEERD-CF. The associated Technical Director was Kurt Kinnevan, CEERD-CVT. The Deputy Director of ERDC-CERL was Dr. Kirankumar V. Topudurti and the Director was Dr. Lance D. Hansen.

COL Ivan P. Beckman was Commander of ERDC, and Dr. David W. Pittman was the Director. 


\section{Unit Conversion Factors}

\begin{tabular}{|l|c|l|}
\hline \multicolumn{1}{|c|}{ Multiply } & \multicolumn{1}{c|}{ By } & \multicolumn{1}{c|}{ To Obtain } \\
\hline British thermal units (International Table) & $1,055.056$ & joules \\
\hline degrees Fahrenheit & $(\mathrm{F}-32) / 1.8$ & degrees Celsius \\
\hline feet & 0.3048 & meters \\
\hline gallons (U.S. liquid) & $3.785412 \mathrm{E}-03$ & cubic meters \\
\hline inches & 0.0254 & meters \\
\hline square feet & 0.09290304 & square meters \\
\hline
\end{tabular}




\section{Acronyms and Abbreviations}

$\begin{array}{ll}\text { Term } & \text { Definition } \\ \text { ANSI } & \text { American National Standards Institute } \\ \text { CERL } & \text { Construction Engineering Research Laboratory } \\ \text { DD } & \text { Department of Defense } \\ \text { DH } & \text { District Heating } \\ \text { DHW } & \text { Domestic Hot Water } \\ \text { ERDC } & \text { U.S. Army Engineer Research and Development Center } \\ \text { ERDC-CERL } & \text { Engineer Research and Development Center, Construction Engineering } \\ & \text { Research Laboratory } \\ \text { HDD } & \text { Heating Degree Day } \\ \text { HQ } & \text { Headquarters } \\ \text { HQIMA } & \text { Headquarters, Installation Management Agency } \\ \text { HQIMCOM } & \text { Headquarters, Installation Management Command } \\ \text { HVAC } & \text { Heating, Ventilating, and Air-Conditioning } \\ \text { MIPR } & \text { Military Interdepartmental Purchase Request } \\ \text { NSN } & \text { National Supply Number } \\ \text { O\&M } & \text { Operations and Maintenance } \\ \text { OMB } & \text { Office of Management and Budget } \\ \text { SAR } & \text { Same As Report } \\ \text { SF } & \text { Standard Form } \\ \text { SIOH } & \text { Supervision, Inspection, and Overhead } \\ \text { SPP } & \text { steam producing power } \\ & \end{array}$


THIS PAGE INTENTIONALLY LEFT BLANK 


\section{Introduction}

\subsection{Background}

Fort Polk is an active Army installation, the home of the Joint Readiness Training Center. Fort Polk provides contingency training for the Army's light infantry and special operation forces, and is also home to Warrior Brigade, which contains several combat support units, the responsibilities of which include supporting the installation. Fort Polk also hosts the newly activated 4th Brigade, 10th Mountain Division.

About 70 barracks, facilities, and administrative buildings on the installation are heated and cooled by central heating and cooling plants. Four plants service the major grouping of barracks, dining facilities, and administrative buildings. The four plants supply chilled water to their local building groups and heating energy to their groups. Two of the plants use distributing hot water systems and two use distributing steam systems.

Figure 1-1 shows the two steam systems situated next to each other in the middle of the installation. Currently, the underground heating piping system has significant maintenance problems that result in leaks, which waste both energy and water. Combining these plants may help overcome these problems and may also improve overall system efficiency.

Figure 1-1 also shows that the two central hot water heating system plants are located at opposite ends of the building area. The isolated chiller plants in these systems perform well, but the chiller sizes are not presently optimized for the chiller demand. Also, most of the buildings connected to this network use a two-pipe distribution system, which requires the installation to choose to use either the heating or cooling medium exclusively. Thus, chilled water is supplied on a seasonal basis. However, since specific local climate conditions cause an occasional demand for chilled water in winter, some buildings are being renovated to have a four-pipe system, which will allow simultaneous use of heating and cooling resources. 
Figure 1-1. Fort Polk site map.

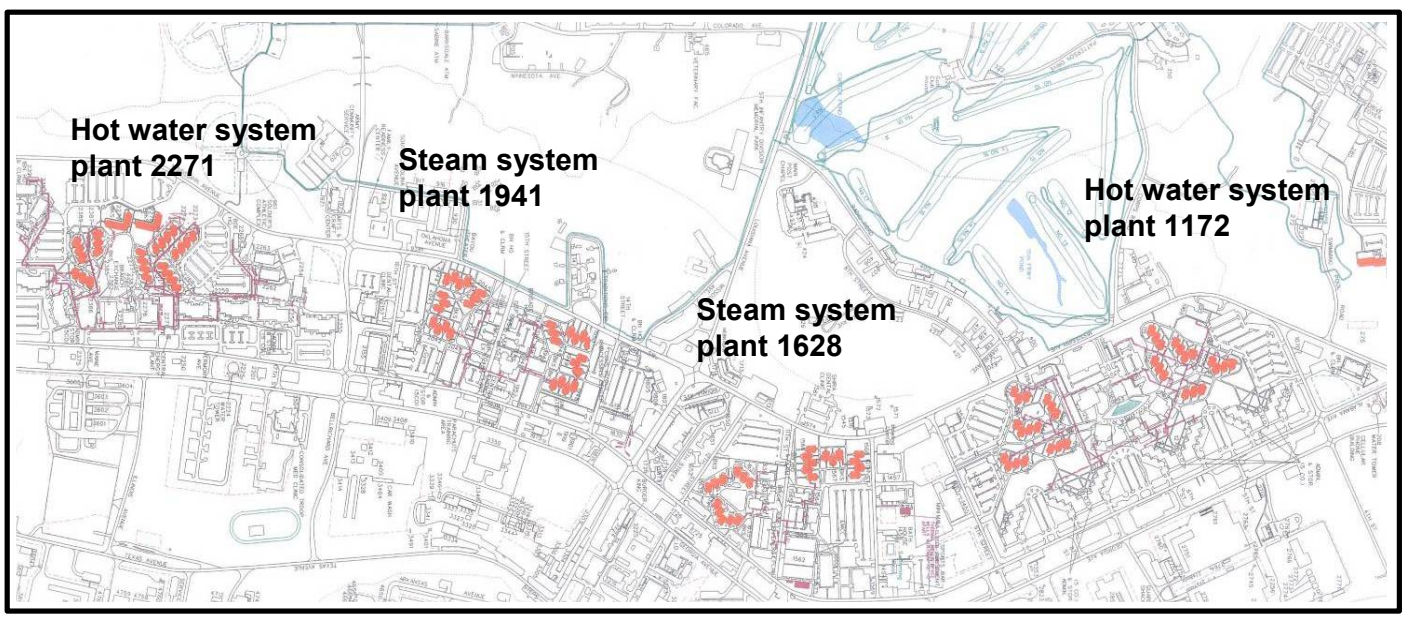

\subsection{Objectives}

The overall objective of this work was to evaluate six heating improvement measures with reasonable installation costs for application to Fort Polk, LA for their ability to

- provide comfort to building occupants

- provide ease of operation

- minimize maintenance

- avoid energy waste.

\subsection{Approach}

An analysis of the steam heating system at Fort Polk was conducted as a pilot project to implement lessons learned from the study Evaluation of European District Heating Systems for Application to Army Installations in the United States. " Field studies and analysis of existing heating systems was followed by technical and economical evaluation of retrofit options.

\footnotetext{
* Alexander M Zhivov, John L Vavrin, Alfred Woody, Donald Fournier, Stephen Richter, Daniel Droste, Satu Paiho, Jenni Jahn, and Reijo Kohonen. 2006. Evaluation of European District Heating Systems for Application to Army Installations in the United States. ERDC/CERL TR-06-20. Champaign, IL: ERDC-CERL, https://erdc-library.erdc.dren.mil/xmlui/bitstream/handle/11681/20086/CERL-TR-06-20.pdf? sequence=1\&isAllowed=y
} 


\section{Site Evaluation}

\subsection{Climatic conditions regard heating demand}

Fort Polk is located in the state of Louisiana, in an area with high humidity and cooling demand, but low heating demand. The low number of heating degree days (HDD) at the installation (Table 2-1) indicates that heating plays only a minor role in the overall building comfort and energy costs. Note that the domestic hot water supply is an important component for showers, etc., for about 4800 soldiers.

\subsection{Estimation and evaluation of the current heating and hot water consumption}

Heat and water consumption is not metered at Fort Polk. For this reason, estimation and assessment of the current heating and hot water consumption were extrapolated from available input data:

- total gas consumption of the Fort Polk

- area of the buildings (square feet)

- numbers of soldiers per building.

Recorded energy and building use information was not sufficient to form a basis for a complete performance analysis. The energy use for each heating plant was unknown and was therefore estimated. Heating demand and annual use of each building was also estimated.

Table 2-1. Heating degree days and design outdoor temperature for four district heating systems.

\begin{tabular}{|l|c|c|c|c|}
\hline & $\begin{array}{c}\text { Mannheim, } \\
\text { Germany }\end{array}$ & Washington & Fort Polk & $\begin{array}{c}\text { Civilian } \\
\text { Facility in } \\
\text { Ohio }\end{array}$ \\
\hline Average HDD $\left({ }^{\circ} \mathrm{C}\right)$ & 3470 & 2250 & 1112 & 3445 \\
\hline Average $\mathrm{HDD}\left({ }^{\circ} \mathrm{F}\right)$ & 6240 & 4045 & 2002 & 6201 \\
\hline $\mathrm{HDD}\left({ }^{\circ} \mathrm{F}\right)$ in 2005 & 6240 & 4194 & no data & 5060 \\
\hline Design Outdoor Temperature $\left({ }^{\circ} \mathrm{C}\right)$ & -12.0 & -9.4 & 2.6 & -16.7 \\
\hline Design Outdoor Temperature $\left({ }^{\circ} \mathrm{F}\right)$ & 10.4 & 15.0 & 36.6 & 2.0 \\
\hline Design Indoor Temperature $\left({ }^{\circ} \mathrm{C}\right)$ & 20.0 & 22.2 & 22.2 & 22.8 \\
\hline Design Indoor Temperature $\left({ }^{\circ} \mathrm{F}\right)$ & 68.0 & 72.0 & 72.0 & 73.0 \\
\hline
\end{tabular}


These estimates were used to perform an initial project assessment to determine if converting Fort Polk to a centralized heating system was potential feasible. If this initial analysis provided favorable results, then more comprehensive measurements of current energy use could be made to provide a more accurate evaluation.

Available information indicated that the total gas consumption of Fort Polk is significantly higher than the heating and hot water energy use of other, similar facilities. Table 2-2 lists data related to important demand side parameters that can be used to compare Fort Polk with other facilities at an aggregated level. The data show that, although Fort Polk had the lowest number of HDD, it had the highest fuel consumption per unit. One possible explanation for this projected high use is that other buildings (in addition to the four boiler plants) use natural gas. Another possible explanation is that the steam heating distribution system may waste a large amount of energy waste through leaks and poorly insulated pipes. The reason for the high fuel consumption was difficult to confirm since, during the site survey, boiler logs were found to be incomplete or missing, and records on natural gas used for cooking and domestic hot water (DHW) heating were unavailable.

\subsection{Heating performance benchmark}

This lack of available data made it difficult to adequately analyze current system performance. Thus, the efficiency of the boilers and the heat losses in the distribution network were estimated to determine if an improvement measure were applicable, and if it would be justifiable to investigate the heating system in more detail.

Table 2-2. Important demand side parameters of four district heating systems.

\begin{tabular}{|l|l|r|r|r|}
\hline & Mannheim, Germany & Washington & Fort Polk & $\begin{array}{c}\text { Civilian } \\
\text { Facility in } \\
\text { Ohio }\end{array}$ \\
\hline Fuel input at boiler level (MWh) & Cogeneration unit & 43,700 & 61,281 & 13,420 \\
\hline $\begin{array}{l}\text { Modeled end user demand incl. } \\
\text { domestic hot water }(\mathrm{MWh})\end{array}$ & $1,600,000$ & 15,544 & 14,418 & $\begin{array}{c}\text { not } \\
\text { applicable }\end{array}$ \\
\hline $\mathrm{M}^{2}$ for heating & No data & 136,000 & 172,521 & 61,000 \\
\hline $\begin{array}{l}\text { Fuel consumption index at boiler } \\
\text { level per }\left(\mathrm{kWh} / \mathrm{m}^{2}\right)\end{array}$ & $\begin{array}{c}\text { Model with hob operation } \\
150\end{array}$ & 321 & 355 & 220 \\
\hline Average $\mathrm{HDD}\left({ }^{\circ} \mathrm{C}\right)$ & 3,470 & 2,250 & 1,112 & 3,445 \\
\hline
\end{tabular}




\subsection{Improvement measures evaluated}

This section lists "improvement measures" noted during the on-site assessment. Each improvement measure is accompanied with a "best guess" analysis. Finally, the sensitivity of these estimations are shown and a further proceeding is recommended.

During the on-site assessment the following improvement measure were noted for further investigation

6. Measure. Switch heating systems in Boiler Plant 1628 and 1941 from steam to hot water.

a. Cost. Associated with building heat exchangers.

b. Savings. Reduced distribution, condensate, and excess building heating losses.

7. Measure. Reduce hot water temperature in the summer (if it is possible to do this with the existing DHW heaters and still provide enough hot water for the barracks).

a. Savings. Reduced distribution losses.

8. Measure. Employ variable hot water flow (which may be better than Measure 2).

a. Savings. Reduced pump horsepower usage.

9. Measure. Run a hot water pipe between Boiler plants 1628 and 1941 to connect the two plants.

a. Savings. Allows use of a smaller boiler in Boiler Plant 1628; currently the 400 hp boiler in Boiler Plant 1941 cycles in the summer since the summer load is too small for full boiler capacity.

10. Measure. Connect Boiler plants systems 1628 and 1941 together and make hot water only in 1941.

a. Costs. Associated with moving the small boilers from Boiler Plant 1628 to 1941.

b. Savings: Reduced outlay to purchase only one set of heat exchangers to heat hot water with steam; less maintenance and operator costs, more efficient boiler operation.

11. Measure. Use jacket water from engine driven chiller to make hot water in Boiler Plant 1941.

a. Costs. Associated with purchase of new heat exchanger.

b. Savings. Lower heating costs. 
Note that insufficient data made it impractical to do a detailed performance analysis of the current system, or an in-depth evaluation of these improvement measures.

\subsection{Estimations for a performance analysis}

Assumptions and experiences gained in other district heating projects were used to obtain a rough performance of the Fort Polk heating systems and to generate the energy flow analysis. These were adjusted to accommodate the conditions at Fort Polk using information gathered during the on-site assessment. Table 2-3 and in Figure 2-1 describe these estimates, which are detailed in the following paragraphs.

Table 2-3. Energy flow list.

\begin{tabular}{|c|c|c|c|c|}
\hline & Heat Energy & Heat Energy & From That & \\
\hline $\begin{array}{l}\text { Natural Gas } \\
\text { Consumption } \\
\text { (MMBtu/a) }\end{array}$ & $\begin{array}{l}\text { House to } \\
\text { Distribution } \\
\text { System } \\
\text { (MMBtu/a) }\end{array}$ & $\begin{array}{l}\text { Distribution } \\
\text { System to } \\
\text { Buildings } \\
\text { (MMBtu/a) }\end{array}$ & $\begin{array}{c}\text { Domestic Hot Water Usage in } \\
\text { Steam District Heating (DH) } \\
\text { Systems } \\
(\mathrm{MMBtu} / \mathrm{a})\end{array}$ & $\begin{array}{l}\text { Space Heating } \\
\text { Usage in Steam } \\
\text { DH Systems } \\
\text { (MMBtu/a) }\end{array}$ \\
\hline 209,151 & 146,400 & 87,840 & 19,450 & 23,940 \\
\hline
\end{tabular}

Figure 2-1. Assumed energy flow.

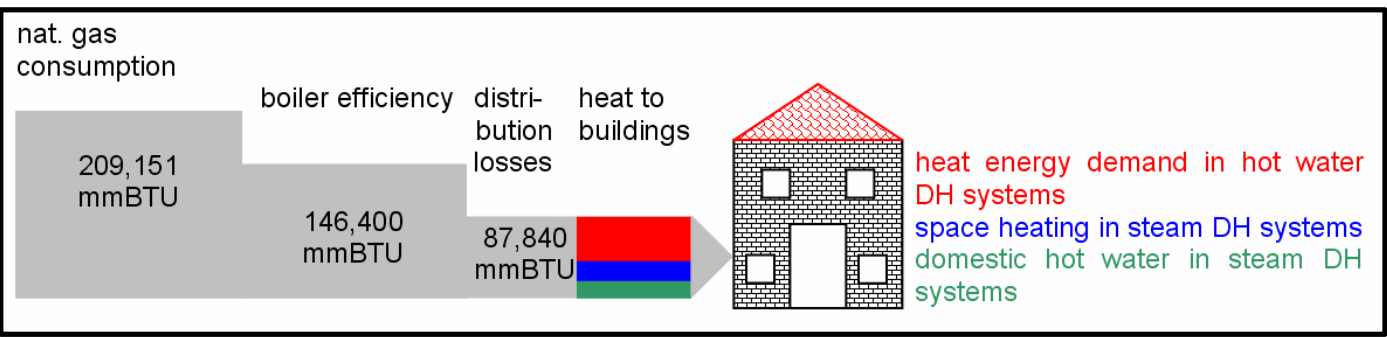

Individual natural gas consumption in the four heating plants in Bldgs. $1172,1628,1941$, and 2271 is unknown. Estimates are based on the installed capacity of these plants (Table 2-4).

Table 2-4. Overview on the four district heating systems at the southern part of Fort Polk and the installed boilers

\begin{tabular}{|l|c|c|c|c|c|}
\hline Location & \# Boilers & $\begin{array}{c}\text { Boiler Size } \\
{[\mathrm{bhp}]}\end{array}$ & $\begin{array}{c}\text { Total } \\
{[\mathrm{bhp}]}\end{array}$ & $\begin{array}{c}\text { Capacity } \\
{[\text { [MBBtuh] }}\end{array}$ & $\begin{array}{c}\text { Connected space heating load } \\
\text { [MMBtuh] }\end{array}$ \\
\hline Plant @ 1172 & 2 & 300 & 600 & 20.112 & 19.30 \\
\hline \multirow{2}{*}{ Plant @ 1628 } & 2 & 150 & 550 & 13.408 & 9.10 \\
\cline { 2 - 6 } & 1 & 250 & & & \\
\hline Plant @ 1941 & 2 & 400 & 800 & 26.816 & 11.30 \\
\hline Plant @ 2271 & 2 & 250 & 560 & 16.76 & 17.75 \\
\hline Total Capacity & & & & 77.096 & 57.45 \\
\hline
\end{tabular}


The last column in Table 2-4 lists the heating energy demand for all the buildings connected to each boiler plant. This value allows a comparison of the connected load and the capacity of each boiler plant. From this data, one can extrapolate that the ratio between the two hot water systems supplied by the boilers in Bldgs. 1172 and 2271 and the two steam systems supplied by the boilers in Bldgs. 1628 and 1941 is about 65\% for hot water heating and $35 \%$ for steam heating. Hence, one can assume that the natural gas consumption in the systems might have the same relation.

This analysis focuses on the steam systems supplied by the plants in Bldgs. 1628 and 1941. Basing on the area of the buildings supplied by the system systems, the total capacity for space heating in the buildings results into 9.10 MMBtuh connected to Bldg. 1628 and 11.30 MMBtuh connected to Bldg. 1941.

Presuming a tank loading system, the domestic hot water system might have an installed capacity of 0.103 MMBtuh at Bldg. 1628 and 0.117 MMBtuh at Bldg. 1941.

The total natural gas consumption in fiscal year (FY) 2005 at the southern part of Fort Polk (where the four district heating systems are situated) was approximately 209,151 MMBtu-presumably consumed at the boiler plants only. This is a conservative estimate since natural gas is used for cooking, domestic hot water preparation, or space heating in some other buildings. Assuming a total mean efficiency of $70 \%$, the heat supplied to the district heat distributions systems is at $146,400 \mathrm{MMBtu}$.

Due to condensate return rates of $30 \%$ and several leakages through the years, water losses, etc., the distribution piping energy losses are estimated to be approximately $40 \%$. This results into 87,840 MMBtu heat energy provided to the buildings.

Taking into account the installed DHW capacity of o.220 MMBtuh and a full load period of $6000 \mathrm{hrs} / \mathrm{yr}$, the energy consumption for DHW preparation in the buildings supplied by the steam systems is estimated to be 19,450 MMBtuh. Hence, 68,390 MMBtu of heat energy remains for building heating.

To simplify, one can assume that the ratio $35 / 65 \%$ of connected space heating load between steam and hot water systems can be applied to the remaining 68,395 MMBtu. From that, 23,940 MMBtu of heat energy 
might be provided to the buildings in the $1500 / 1600$ and 1900/2000 areas connected to the steam systems.

Dividing this amount of energy by the installed space heating capacity of 20.4 MMBtuh yields a full load period of $1180 \mathrm{hrs} / \mathrm{yr}$. Recalling the discussion above, less than $1200 \mathrm{hrs} / \mathrm{yr}$ of full load period seems reasonable.

\subsection{Steam heating conversion to variable temperature hot water heating}

\subsubsection{Energy savings}

Assuming that the conversion from steam to variable temp and flow hot water systems is feasible, it may be possible to increase boiler efficiency up to $85 \%$ and to reduce distribution losses to $10 \%$. Nevertheless, the demand of $43,400 \mathrm{MMBtu}$ of heat energy required in the buildings in the $1500 / 16000$, 1900/2000 areas for space heating and DHW preparation will continue.

At this level of efficiency, the natural gas consumption will amount to about 54,900 MMBtu or 549,000 therms. By comparison, the boiler efficiency is currently assumed to be $70 \%$ and the distribution losses $40 \%$. Thus, the current natural gas consumption in the steam systems amounts to 79,000 MMBtu or 790,000 therms. It follows then, that these improvements will yield a natural gas saving of $24,100 \mathrm{MMBtu}$ or 241,000 therms.

\subsubsection{Savings from a steam to variable temp and flow hot water systems and required initial investments}

\subsubsection{Investment costs for hot water conversion}

Conversion from a steam heating distribution system to a hot water distribution systems will require installation of new equipment in the boiler plants, and new piping and new equipment in the mechanical rooms of each building served. The new equipment will include heat exchangers, pumps, controls, and piping (Table 2-5). The estimated cost for this conversion is $\$ 3,471,000$. 
Table 2-5. List of assumed costs for a conversion of the two steam district heating systems to one hot water system with variable temperatures.

\begin{tabular}{|cl|r|}
\hline Item & Cost $\mathbf{( \$ U . S . )}$ \\
\hline 1 & Building Interfaces & $1,000,000$ \\
\hline 2 & Building steam uses & 50,000 \\
\hline 3 & Piping & $1,500,000$ \\
\hline 4 & Central heat exchanger & 100,000 \\
\hline 5 & Pumps and controls & 80,000 \\
\hline 6 & Makeshifts, etc. & 50,000 \\
\hline 7 & Moving of boilers, etc. & 70,000 \\
\hline 8 & Misc. investments & 150,000 \\
\hline Subtotal & $3,000,000$ \\
\hline 9 & $10 \%$ contingency & 300,000 \\
\hline 10 & $\begin{array}{l}5.7 \% \text { Supervision, Inspection, } \\
\text { and Overhead (SIOH) }\end{array}$ & 171,000 \\
\hline Total & $3,471,000$ \\
\hline
\end{tabular}

\subsubsection{Estimated first costs}

The estimated first costs for each of the items are based on engineering assumptions and hands-on experience from other projects, coupled with information gathered during the on-side assessment. These numbers and cost estimations are "best guesses" and can easily vary by 20 to $30 \%$.

\subsection{Building interfaces}

Twenty-four buildings are connected to both steam heating systems in the $1500 / 1600$ and in the $1900 / 2000$ areas. The total connected load is about 20.302 MMBtuh for space heating and an additional 0.120 MMBtuh for DHW preparation. For each building, the heat exchangers for space heating as a compact station will cost about \$400,000. Also, each building will require heat exchangers and DHW storage tanks with a storage capacity of 19,200 gal. This scenario includes a tank loading system with a full load period of $8 \mathrm{hrs}$. These devices will have a total estimated cost about \$440,000. Some buildings might need an additional building extension, which can incur further costs. Another cost to consider is that of the labor required to replace the current equipment with new compact stations. (An additional cost of $\$ 150,000$ can easily occur.) Hence, the total costs for the building interfaces are about $\$ 1,000,000$. 


\subsection{Other steam uses in the building}

It was not clear whether the steam generated by the steam heating system is also used in the buildings directly, for ironing, air conditioning, sterilization, or other purposes. The conversion from a steam to a hot water distribution system must account for some solutions for these direct steam users. An estimated investment of $\$ 50,000$ should cover these costs.

\subsection{Piping}

It is hard to estimate the costs for piping without going into details, since the costs depend directly on pipe diameter and footage. The experience from Europe is that steam pipes can be used- to some extent-for hot water transport. A reliable estimate would require a detailed hydraulic analysis of the piping system. This analysis can be used to develop a conceptual view of the systems that shows where the bottlenecks are and how to handle them. Furthermore, it is not clear if the existing pipes are in sufficiently good condition to charge them with the higher pressures and weights associated with transporting hot water instead of steam. Experiences from district heating (DH) systems of the dimension of about 20,000 MMBtuh show that it should be possible to toughen up the steam systems for hot water service for costs of $\$ 1,000,000-\$ 1,250,000$. Additionally, connecting the two steam systems into one common system will require installing about $1700 \mathrm{ft}$ of additional pipeline. This line might be composed of 4-in. pipe with special costs of $\$ 150 / \mathrm{ft}$, at a cost of about $\$ 250,000$. Hence, the first cost to adjust the steam piping system for hot water service will be at least $\$ 1,500,000$.

\subsection{Central heat exchanger}

The existing boilers can provide steam only. To use these boilers in a hot water distribution system will require the installation of heat exchangers. The system capacity must be large enough to satisfy the demand at peak load conditions and also to satisfy the demand if (or when) one heat exchanger unit shuts down. Conservatively, the central heat exchangers need a capacity of 25 MMBtuh, which is the capacity of the connected load in the buildings of the 1500/1600 and 1900/2000 area. Without all the controls, fittings, valves, etc., this will cost at least $\$ 100,000$. 


\subsection{Pumps and controls}

New pumps, controls, fitting, valves, etc. will incur additional first costs. Assessing something more than $\$ 7 /$ Btuh installed capacity for the heat exchangers and the control units and pumps, the pumps and controls will cost $\$ 80,000$.

\subsection{Makeshifts, etc.}

Converting a steam DH system to a hot water system will take some time (about 3 months). During this time, the buildings will still require hot water. Rental boilers are available for this purpose. These rental boilers must supply the 0.120 MMBtuh DHW thru the conversion period. An amount of $\$ 50,000$ should be adequate to rent and maintain the boilers for 3 months and to move them from building to building.

\subsection{Moving of boilers, etc.}

One proposed scenario considers reducing the numbers of boiler sites. This scenario would is move both 150 bhp boilers from Bldgs. 1628 to 1941 at an estimated cost of $\$ 70,000$, including labor and technical installation.

\subsection{Misc. investments}

Since all the first investment costs discussed above involve a number of uncertainties and are based on engineering assumptions and subjective experience, an additional $\$ 150,000$ should be allowed for miscellaneous investments.

\subsection{0\% contingency and $10.5 .7 \% \mathrm{SIOH}$}

These two cost items (contingency and Supervision, Inspection, and Overhead [SIOH]) are standard cost items for an Army major construction project.

\subsubsection{Potential savings}

Major savings are expected from reduced use of natural gas. At a natural gas cost of $\$ 1.20 /$ therm, annual savings amount to $\$ 290,000$. The system will also accrue savings in reduced operation and maintenance (O\&M) costs. The annual cost of repairs can be reduced; a reasonably assumed saving potential might be about $\$ 100,000$. Better piping systems with a leak control system will reduce the costs associated with condensate water losses, resulting in estimated savings as great as $\$ 20,000$. 
Beyond the O\&M savings, one must consider that hot water systems require more electricity (to pump water) than a comparable steam system (an estimated $\$ 15,000 / y r$ ). In total, the annual savings is estimated to be $\$ 395,000$. Thus the simple payback time will be about 8.7 years.

This value is felt to be quite conservative since all the natural gas used in the southern part of Fort Polk is applied to these heating systems. Reducing the natural gas use of these boilers will reduce the energy cost savings and thus cause a longer simple payback period.

Another important influence on the natural gas savings is the efficiencies of the boilers and the distribution system heat losses. Estimates in this work used maximum values for both to provide the greatest savings. If the current losses or the improvements are not as great as assumed, the savings would be less. This again would result in a longer simple payback period. For example, one can assume $80 \%$ efficiency as an achievable boiler efficiency and the distribution might be reducible down to $30 \%$ only. Thus, annual natural gas savings will amount to only 11,300 MMBtu/a or 113,000 therms, which would result in a simple payback 14.4 years. Table 2-6 lists the considerations used in the preceding sensitivity analysis.

Table 2-6. Overview on the sensitivities of the investments and potential savings and its impacts on the pay-back time

\begin{tabular}{|c|c|c|c|c|c|c|}
\hline Investments & \multicolumn{2}{|c|}{ parameters } & $\begin{array}{c}\text { nat. gas } \\
\text { savings }\end{array}$ & $\begin{array}{c}\text { nat. gas } \\
\text { price }\end{array}$ & $\begin{array}{c}\text { other } \\
\text { savings }\end{array}$ & $\begin{array}{c}\text { pay-back } \\
\text { time }\end{array}$ \\
\hline $\mathbf{( \$ )}$ & $\begin{array}{c}\text { boiler } \\
\text { efficiency }(\%)\end{array}$ & $\begin{array}{c}\text { distribution } \\
\text { losses }(\%)\end{array}$ & $($ MMBtu/a) & $(\$ /$ therm) & $(\$)$ & SPP, ${ }^{*}$ yrs \\
\hline $3,471,000$ & 85 & 10 & 24,100 & 1.20 & 105,000 & 8.7 \\
\hline $3,471,000$ & 80 & 30 & 11,300 & 1.20 & 105,000 & 14.4 \\
\hline
\end{tabular}




\section{Conclusions and Recommendations}

\subsection{Conclusions}

After assessing the heating system at Fort Polk, LA and evaluating six heating improvement measures for application at that installation, this work concludes that (1) potential savings are not significant enough to warrant the high investments required for retrofit, and (2) the energy flow data available to this study were not sufficient to perform a complete performance analysis.

The rough calculations done in this study show that the savings appear to be too small to warrant the investment required to conversion convert the steam heating distribution system to a hot water system. The most optimistic estimated simple payback period of almost 9 years may easily be much longer if projected savings are less or if implementation costs greater than those used in these preliminary findings. The most important reason for the small savings is the southern climatic conditions and the structure of the DH system itself. In other words, the heating load on the DH systems is too small to make such a change economical.

In comparison to a decentralized system with a single boiler in each building, the load on a DH system is very important. The first costs are relatively high in a DH system, although the operation costs are quite low compared with the decentralized system. The 1200 full load hours experienced at Fort Polk are due to the site climatic condition; this is a low value compared to other district heating systems. Both steam DH systems are small in terms of connected load as well. In fact, the steam district heating systems at Fort Polk does not have the opportunity to operate the installations heat generation and distribution at full capacity. A larger system would offer the chance to operate the installations longer at full capacity due to the adjusted average of the load profiles.

Additionally, the ERDC-CERL project delivery team reviewed the DD1391 for a project at Fort Polk to improve the performance of the chilled water plants. The team concluded that the approach and concept were correct for this application. The team reached the following conclusions

1. This project would enable the cooling systems to operate in the winter time. On the occasional warm day, the system could cool the building spaces and keep the occupants kept comfortable. Currently, facilities receive only heating in the winter and on warm winter days so that the space 
temperatures become uncomfortably warm. Some occupants turn off their ventilation systems to keep building temperatures comfortable.

2. In the winter, the inability to cool the ventilation air in the barracks leads to mold problems. Currently, the humidity created by showers remains in the living quarters, and the building's exhaust system draws more humid air from outside into the barracks. With no chilled water, the HVAC's cooling coil cannot reduce the rooms' humidity level.

3. The chiller plants will be interconnected to provide better chiller operations at low winter time loads, when one or two chillers can provide chilled water for the entire site. This will also increase the security of supply; when one chiller's operation is interrupted, another chiller can carry the load.

4. In the winter time, a water-side economizer can provide the cooling water. This system uses cooling tower water as the cooling source. A heat exchanger keeps the cooling tower water separate from the chilled water. When the outdoor temperature drops below $50^{\circ} \mathrm{F}$, a cooling tower can generate $55^{\circ} \mathrm{F}$ chilled water, which is then sent to the buildings.

5. Variable flow water pumping systems should be installed to better use the chilled water. The current system sends chilled water to the buildings at a constant flow so, if not needed, the chilled water is bypassed and returned to the chiller plant, and a full $10^{\circ} \mathrm{F}$ drop is not achieved. If the building HVAC systems used two way valves, all the water would run through the cooling units, and none would be bypassed. The resulting reduction in water flow would yield pump energy savings and provide more flow to buildings that previously had difficulties getting adequate chilled water.

\subsection{Recommendations}

In general, it is difficult to make investment recommendations based on incomplete energy use information. Consequently, this work recommends that Fort Polk implement and enforce a metering campaign to improve the installation's energy use database. More detailed energy use data collected over time will enable informed decisions about heating system improvements. The database and the knowledge about the energy flows can be improved by taking the following proposed measures

- Technical measures (metering)

- Install (at least) sub gas meters for the boilers and important sub gas consumers (e.g., kitchens, cleaning station, hospital)

- Install steam/hot water production meters at the boilers

- Meter make up water 
- Install water meters for hot water at the building level

- Perform leak detection in the hot water, steam, and condensate systems.

- Operational measures

- Perform at least 1 year of weekly meter readings

- Do regular data analysis, especially to detect irregularities

- Define and implement heating, hot water, and gas consumption norms specific to Fort Polk

- Benchmark performance.

A metering campaign will result into a better knowledge and understanding of the energy flows, usage, and demand. From that data, it will be possible to locate weak points where energy (and money) is wasted. An analysis of these weak points can show how to improve the system efficiency and can help determine which energy supply system is best suited for Fort Polk. 


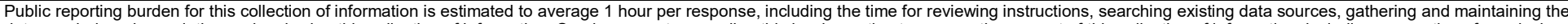

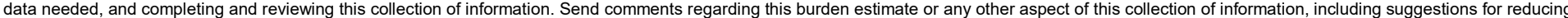

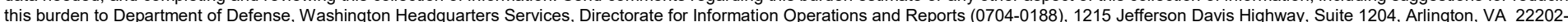

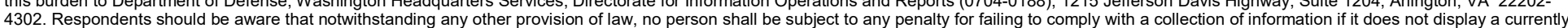
4302. Respondents should be aware that notwithstanding any other provision of law, no person shat
valid OMB control number. PLEASE DO NOT RETURN YOUR FORM TO THE ABOVE ADDRESS.
\begin{tabular}{l|l} 
valid OMB control number. PLEASE DO NOT RETURN YOUR FORM TO THE ABOVE ADDRESS. \\
\hline 1. REPORT DATE (DD-MM-YYYY) & $\mathbf{2 . ~ R E P O R}$
\end{tabular}
o8/28/2018
2. REPORT TYPE Final

al

\section{TITLE AND SUBTITLE}

Analysis of Steam and Hot Water Heat Systems at Fort Polk, LA:

Retrofit Options

E

ran

.

\section{DATES COVERED (From - To)}

\section{5a. CONTRACT NUMBER}

MIPR 6CCERB1011

5b. GRANT NUMBER

\section{5c. PROGRAM ELEMENT}

\section{AUTHOR(S)}

Alexander M. Zhivov, John L. Vavrin, Alfred Woody, Stephen Richter, and Norbert Paetz

\section{5d. PROJECT NUMBER}

Project Requisition No. 127396

5e. TASK NUMBER

Activity A1020

5f. WORK UNIT NUMBER

7. PERFORMING ORGANIZATION NAME(S) AND ADDRESS(ES)

U.S. Army Engineer Research and Development Center (ERDC)

Construction Engineering Research Laboratory (CERL)

PO Box 9005,

Champaign, IL 61826-9005

8. PERFORMING ORGANIZATION REPORT NUMBER

ERDC/CERL TR-18-23

\section{SPONSORING / MONITORING AGENCY NAME(S) AND ADDRESS(ES)}

Headquarters, Installation Management Command (HQIMCOM)

2405 Gun Shed Road

Joint Base San Antonion Fort Sam Houston, TX 78234-1223

\section{DISTRIBUTION / AVAILABILITY STATEMENT}

Approved for public release; distribution is unlimited.

\section{SUPPLEMENTARY NOTES}

\section{ABSTRACT}

Fort Polk is an active Army installation, with about 70 barracks, operations, and administrative facilities, all of which are heated and cooled via central heating and cooling plants. Two of the building groups are heated by distributing hot water and the other two by steam. Although the existing equipment in the heating plants appears to be in good condition, the system's underground heating piping has significant maintenance problems. Also, while the isolated chiller plants perform well, they are not optimized for the chiller demand. This work assessed the heating system at Fort Polk, LA and evaluated heating improvement measures for application at that installation, and concluded that (1) potential savings were not significant enough to warrant the high investments required for retrofit, and (2) available energy flow data were insufficient to perform a complete performance analysis. It was recommended that the installation implement and enforce a metering campaign to improve its energy use database and to better enable informed decisions about heating system improvements.

\section{SUBJECT TERMS}

Fort Polk (La.)--Heating and ventilation, Fort Polk (La.)--Cooling systems, Fort Polk (La.)--Energy consumption, Buildings--Retrofitting

\section{SECURITY CLASSIFICATION OF:}

\section{a. REPORT}

Unclassified

\section{b. ABSTRACT}

Unclassified c. THIS PAGE

Unclassified

17

\begin{tabular}{c|c|c} 
17. LIMITATION & $\begin{array}{c}\text { 18. NUMBER } \\
\text { OF ABSTRACT }\end{array}$ & $19 a$ \\
OF PAGES & & \\
\cline { 3 - 3 } & &
\end{tabular}

19a. NAME OF RESPONSIBLE PERSON

19b. TELEPHONE NUMBER

(include area code) 